\title{
PELATIHAN KEWIRAUSAHAAN BAGI SISWA SMK KARTINI SURABAYA
}

\author{
${ }^{1 *}$ Dwi Bhakti Iriantini, ${ }^{2}$ Wiwik Herawati, ${ }^{3}$ Giyana \\ Universitas Wijaya Kusuma, Surabaya, Jawa Timur, Indonesia \\ Email : *dwibhaktiiriantini@uwks.ac.id
}

Manuskrip: Juni -2021; Ditinjau: Juni -2021; Diterima: Juli -2021; Online: Juli-2021; Diterbitkan: Juli-2021

\begin{abstract}
ABSTRAK
Kewirausahaan merupakan bidang yang masih kurang diminati oleh kalangan remaja.walaupun upaya yang sudah dilaksanakan oleh pemerintah dan pihak swasta sudah banyak, namun masih perlu dukungan banyak pihak, Tujuan kegiatan pengabdian kepada masyarakat ini untuk menanamkan jiwa kewirausahaan sejak dini pada siswa. Diharapkan pada waktu yang akan datang para siswa menjadi wirausahawan yang handal dan professional.Kegiatan ini dilakukan oleh team pengabdi masyarakat Fakultas Ekonomi dan Bisnis Universitas Wijaya Kusuma Surabaya dan bekerja sama dengan Kepala Sekolah SMKKartini Surabaya, dari bulan Maret 2021 sampai bulan Agustus 2021. Jumlah siswa yang dibina dalam kewirausahaan sebanyak 35 orang, metode pelaksanaan kegiatan ini menggunakan pendekatan pelatihan kewirausahaan disertai contoh pembuatan produk makanan frozen. Adapun pelaksanaan kegiatan pelatihan dilakukan dengan pemberian materimembangun jiwa kewirausahaan
\end{abstract}

\section{Kata Kunci: Kewirausahaan}

\section{PENDAHULUAN}

Kewajiban setiap perguruan tinggi sebagaimana dijelaskan dalam Tri Dharma Perguruan Tinggi yang meliputi pendidikan, penelitian dan pengabdian masyarakat. Untuk kegiatan yang berupa pengabdian pada masyarakat bagi perguruan tinggi merupakan jembatan komunikasi antara perguruan tinggi dengan masyarakat, dari pengabdian masyarakat ini perguruan tinggi akan mengetahui keinginan serta kebutuhan masyarakat.

Kegiatan sosialisasi penyuluhan pelatihan keterampilan pembuatan makanan frosen ini adalah untuk membentuk karakter sejak dini kepada siswa SMK Kartini Surabaya agar selain mereka memiliki pendidikan formal juga memiliki modal ilmu keterampilan agar bisa membuat makanan frosen. Tujuan yang dilakukan sangat jelas dan bermanfaat bagi siswa setelah mereka lulus dari SMK dan memiliki jiwa mandiri entrepreneur. Siswa dituntut memiliki kemandirian finansial selepas lulus dari SLTA dan Perguruan Tinggi. Tidak mudah dalam kemandirian finansial tersebut, proses yang tidak mudah, proses yang tidak cepat, diperlukan jiwa kemandirian dari waktu ke waktu. 
Pelatihan seperti ini sangat diperlukan oleh para siswa, karena jiwa dan pengetahuan mereka masih sangatminim, maka pendampingan untuk membentuk karakter menumbuhkan jiwa kemandirian bewirausaha sangat dibutuhkan oleh mereka. Potensi siswa bisa dibetuk dengan adanya penyuluhan dari tim abdimas. Tak kalah penting kendala lain dari para siswa adalah kurangnya motivasi.

Salah satu upaya yang kami lakukan sebagai tim abdimas FEB Universitas Wejaya Kusuma adalah memberikan pengetahuan materi membangun jiwa kewirausahaan dan yang terpenting yaitu melatih para siswa memiliki keterampilan dam membuat produk. Hal ini dilakukan karena prospek pembuatan makanan trosen sangat baik dan tidak memerlukan modal besar, namun diperlukan ide kreafi inovatif. Dengan adanya penyuluhan pelatihan keterampilan pembuatan produk ini diharapkan dapat mengasah kemampuan mereka danmenjadi lebih semangat dalam berwirausaha, terutama mendapatkan uang saku dan siswa lebih mandiri terhadap finasial

Bedasarkan latar belakang maka perumusan masalahsebagai berikut : Bagaimana menumbuhkan jiwa kewirausahaan siswa SMK Kartini Surabaya melalui pelatihan pembuatan makanan frozen adapun tujuan kegiatan pelatihan kewirausahaan bagi siswa di SMK Kartini ini memberikan pengetahuan tentang menumbuh kembangkan jiwa kewirausahaan siswa SMK Kartini melalui pembuatan makanan frozen dan memberikan pengetahuan cara membuat produk makanan frozen.

Manfaat yang diperoleh dalam kegiatan ini adalah :dengan dilaksanakannya pengabdian masyarakat ini maka diharapkan para siswa dapat mengembangkan kreativitas dan mendorong semangat entrepreneur untuk meningkatkan pengahasilan tambahan bagi bagi siswa

\section{METODE}

Penyuluhan kewirausahaan dan pemberian motivasi dilakukan dengan Ceramah digunakan untuk penyampaikan pengetahuan secara umum tentang manfaat berwirausaha, peluang wirausaha dan langkah-langkah untuk menjadi seorang wirausaha yang suksesmelalui multi media

Demonstrasi digunakan untuk memberikan keterampilan secara langsung mengenaiproses pembuatan makanan frosen. Pelatihan pembuatan makanan frosen ditujukan untuk memberikan pengetahuan kepada para siswa untuk menumbuhkan jiwa wirausaha para siswadan membangkitkan semangat mereka untuk memulai usaha salah satunya melalui pembuatan produk makanan frosen

Evaluasi hasil pelatihan dilakukan selama proses dan setelah kegiatan pelatihan dilaksanakan. Evaluasi ini ditujukan untuk perbaikan di masa yang akan datang, untuk menjadikan kegiatan pengabdian kepada masyarakat ini menjadi salah satu kegiatan memberikan manfaat yang besar baik bagi masyarakat maupun bagi dosen sebagaipenyelenggara kegiatan ini.

Dalam kegiatan pengabdian kepada masyarakat ada beberapa langkah yang dilakukan teampengabdi diantaranya :1 Survey Pendahuluan : Kegiatan Survey pendahuluan tujuannya untuk mengetahui aktifitas calon peserta pengabdian sesuai 
yang direncanakan yaitu para siswa Disamping untuk mengetahui lokasi rencana kegiatan apakah lingkungan yang dituju secara ekonomi sudah cukup atau perlu dibina untuk berwirausaha. 2.Observasi Data siswa :Kegiatan observasi data siswa ini dilakukan ke SMK Kartini Surabaya,tujuannya untuk mengetahui Kegiata para siswa selain belajar formal. 3. Penjaringan Peserta Pengabdian

Kegiatan ini dilakukan oleh team pengabdi dan bekerja sama dengan Kepala Sekolah SMK Kartini Surabaya.

\section{HASIL DAN PEMBAHASAN}

Pelaksanaan kegiatan pegabdian kepada masyarakat ini telah terlaksana dengan baik bertempat di SMK Kartini Surabaya. Tim pelaksana dari program studi Manajemen UWKS , Terlaksananya kegiatan pengabdian kepada masyarakat ini sesuai dengan jadwal yang telah ditetapkan dan disepakati oleh SMK Kartini Surabaya sebelum kegiatan ini dilaksanakan

Pengabdian kepada masyarakat ini telah melalui beberapa tahapan. Tahapan pertama dimulai dengan melakukan tahap persiapan, pada tahapan ini dimulai dengan mempersiapkan proposal kegiatan pengabdian pada masyarakat, selanjutnya dilakukan observasi dan permohonan izin kepada pihak sekolah SMK Kartini Surabaya sebagai tempat pelaksanaan pengabdian ini. Disamping itu juga mengumpulkan informasi mengenai jumlah peserta yaitu jumlah siswa yang akan mengikuti pelatihan pembuatan makanan frosen

Tujuan dari kegiatan pelatihan ini dilaksanakan adalah dalam rangka pelaksanaan Tri Dharma Perguruan Tinggi UWKS, yang salah satunya adalah pengabdian pada masyarakat. Pelatihan ini ditujukan kepada siswa kelas X sebagai sasaran pemberdayaan pelatihan keterampilan dipilih karena beberapa alasan, diantaranya: masih belum padat dan berat beban mata pelajarannya sehingga waktu yang luang bisa dimanfaatkan secara positif, masih berperilaku seperti anak Sekolah Menengah Pertama (SMP). Remaja Kelas X mempunyai karakteristik masa remaja (12-21 tahun) yang merupakan masa peralihan antara masa kehidupan anak-anak dan masa kehidupanorang dewasa. (Desmita.2009: 37).

Tahap kedua adalah Tahapan pelaksanaan kegiatan dimulai dengan menjelaskan materi tentang kewirausahaan, maknadari kewirausahaan, langkah dan tahapan menjadi seorang wirausaha, manfaat dari berwirausaha, dan peluangpeluang usaha untuk memotivasi peserta dalam pemanfaatan waktu luang untk mencipatakan produk makanan frosen yang bernilai ekonomi bagi peningkatan produktivitas jiwa entrepreneurserta memberikan contoh contoh pengusaha sukses diusia muda.

Dari pemberian materi kewirausahaan tersebut selanjutnya Tim Abdimas memberikan contoh-contoh produk makanan frosen yang sedang trend di semua kalangan terutama remaja, seperti: siomay, gyosa, pastel, risoles ,kroket, bakso, sosis,sosis solo,brule boom. Pilihan siswa jatuh pada pembuatan pastel dan kroket dengan aneka isi yang berbeda beda.

Tahapan pelaksanan selanjutnya yaitu demonstrasi pembuatan pastel dan kroket dengan varian isi yang berbeda beda secara langsung. Tahapan pelatihan 
diberikan kepada setiap peserta berupa uraian atau langkah-langkah pembuatan pastel dan kroket dengan menggunakan alat dan bahan yag telah disiapkan sebelumnya. Perserta diberi kesempatan untuk melakukan tanya jawab dan diberikan pengarahan oleh tim abdimas pada saat pelatihan berlangsung, tim abdimas menjelaskan langkah-langkah pembuatan pastel dan kroket beserta varian isi yang berbeda beda dan langsung mendemostrasikan kepada peserta pelatihan.

Peserta diberi kesempatan untuk mempraktekan secara langsung pembuatan pastel dan kroket satu persatu kedepan secara bergantian. Setelah dilakukan pelatihan diharapkan siswa SMK Kartini Surabaya dapat membuat pastel dan kroket dengan varian isi yang berbeda beda, guna menambah penghasilan mereka. Selain itu, diharapkan para peserta pelatihan dapat mengembangkan produk yang memiliki daya jual yang berdaya saing.

Foto Kegiatan :
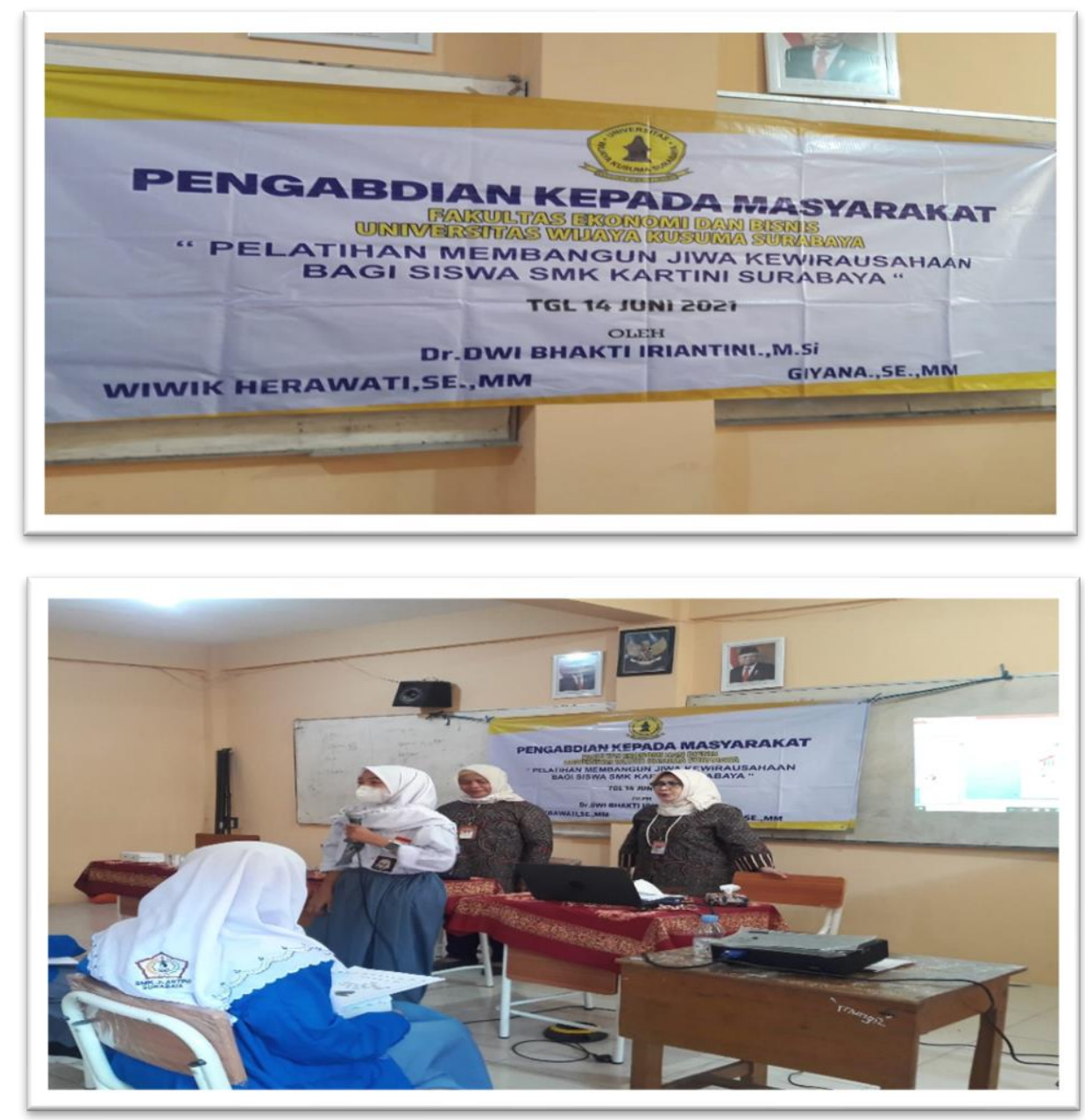

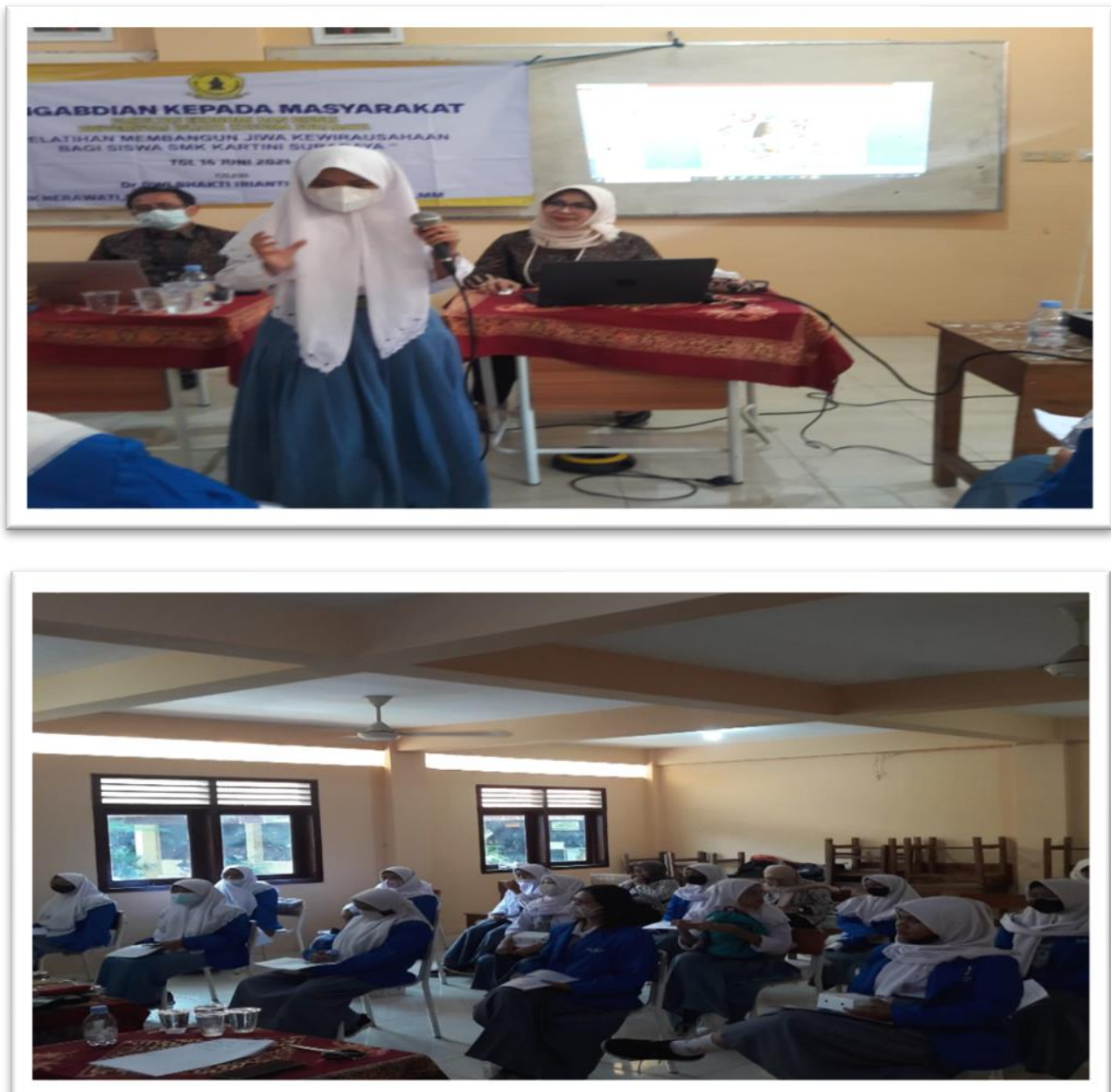

Setelah kegiatan ini selesai dilaksanakan, maka tim abdimas melakukan evaluasi. Adapun evaluasi dari kegiatan ini dapat dinyatakan secara umum berhasil dengan baik dan memuaskan peserta siswa SMK kartini Surabaya maupun tim abdimas yang memberi pelatihan ini sendiri. Pelatihan ini mendapatkan sambutan yang hangat dan antusias yang sangat baik dari pihak tempat terselenggaranya pelatihan ini.

Untuk menjembatani siswa yang mengalami kesulitan dalam mempraktekkan hasil makanan frosen ini, tim abdimas memberikan kesempatan pada siswa untuk berkoordinasi setiap hari Sabtu melaui daring selama 3 bulan. Mereka berharap pelatihan ini dapat dilaksanakan untuk tahun-tahun berikutnya.

\section{KESIMPULAN}

Kegiatan pengabdian kepada masyarakat berupa kegiatan pelatihan pembuatan pastel dan kroket dengan varian isi yang berbeda beda yang diadakan di SMK Kartini Surabaya secara keseluruhan dapat berjalan baik dan lancar. Pelatihan ini memberikan keterampilan wirausaha kepada siswa SMK Kartini sebagai bekal wirausaha, atau pun sebagai bekal untuk memulai usaha sampingan 
mereka.Pemaparan materi kewirausahaan diharapkan dapat memacu semangat para siswa dalam melakukan kegiatan wirausaha salah satunya melalui penciptaan makanan frozen.

Peningkatan dan pengembangan keterampilan oleh siswa SMK Kartini Surabaya akan berdampak terhadap pertumbuhan usaha rumah tangga yang nantinya mampu meningkatkan pendapatan siswa sekaligus dapat menciptakan lapangan usaha bagi siswa. Selain itu, kegiatan ini juga akan memberikan manfaat bagi masyarakat sekitar karena dapat menyediakan produk makanan frosen berkualitas dan bermutu yang kualitasnya sama dengan produk yang diciptakan kompetitor dengan harga yang lebih murah.

\section{SARAN}

Masih ada peserta yang menghasilkan produk kurang sempurna baik dari bentuk dan rasaakibat dari singkatnya waktu pelatihan karena sering absen dan penyesuaian waktu yang kurang tepat, sehingga memerlukan negosiasi dan musyawarah dengan pihak sekolah. Pihak sekolah meminta kegiatan ini berlanjut dengan materi dan produk yang berbeda, sehingga kreativitas peserta didik bisa lebih berkembang.

Terimakasih kami ucapkan kepada semua pihak yang mendukung kelancaran pengabdian ini terutama untuk Sekolah Menengah Kejuruan (SMK) Kartini Surabaya dan kepada Tim abdimas FEB Universitas Wijaya Kusuma Surabaya

\section{DAFTAR PUSTAKA}

Akbar, I. R., et al. (2021). Peningkatan Minat Wirausaha Pada Siswa SMK Muhammadiyah Parung Kabupaten Bogor. Jurnal PADMA: Pengabdian Dharma Masyarakat, 1(2).

Ardista.2014. Generasi Millennial dalam Era Ekonomi Kreatif. Diakses melalui: http://news.indonesiakreatif.net/gen-millennial

Arsdel, Michael, Robert. Quality and Stability of Frozen Foods: Time- Temperature Tolerance and its Significance. Pg. 67-69

Desmita. 2009. Psikologi Perkembangan Peserta Didik. Bandung: PT Remaja Rosdakarya

Dewanti, R. N., et al. (2021). Penyuluhan Dan Pelatihan Keterampilan Sablon Pigment Pasta Manual Di Karang Taruna 03 Desa Cisauk. Jurnal PADMA: Pengabdian Dharma Masyarakat, 1(1).

Erlangga, H, et al. (2019). Pengaruh Kegiatan Promosi Terhadap Keputusan Pembelian Konsumen Pada PT. Modise Busana Sejati Di Bandung. Jurnal Ekonomi Efektif, 1(4).

Howkins, John. 2001. The Creative Economy. Inggris: Penguins Book Hisrich,,RD Peters, dan Sheperd DA ( 2008 ), Kewirausahaan edisi 7, EdisiBahasa Indonesia ,Jakarta,Salemba Empat

Mathlouthi, M. Food Packaging and Preservation. Pg 112-115

Mutis, T. (1995).Kewirausahaan yang Berproses. Jakarta: PT Grasindo. 
Rachbini, D.J. (2001). Pengembangan Ekonomi \& Sumber Daya Manusi a, Penerbit Grasindo, Jakarta

Smithers, Rebecca (February 10, 2012). "Sainsbury's changes food freezingadvice in bid to cut food waste". The Guardian.

Suryana. (2003). Kewirausahan: Pedoman praktis, kiat dan proses menuju sukses (Edisi Revisi). Jakarta: Salemba Empat.

Tressler, Evers, Evers. Into the Freezer - and Out. Pg 56.

Tressler, Evers. The Freezing Preservation of Foods Pg 213-217.

Yusuf, Nasrullah(2006), Wirausaha danusaha kecil, Jakarta,Modul PTKPNF,Depdiknas

Zakiul.J. 2014.Indonesia dalam Menghadapi Era Baru Ekonomi Kreatif.Diakses melalui:http://news.indonesiakreatif.net/era-ekonomi-kreatif. 